\title{
Determinan Faktor yang Mempengaruhi E-Trust dan Minat Menggunakan Aplikasi Alodokter
}

\section{Kadek Yoga Kusuma Pradita ${ }^{1 *}$}

1Universitas Pendidikan Nasional, Indonesia

\section{ART ICLE IN F O}

Article history:

Received August 19, 2021

Revised August 20, 2021

Accepted September 30, 2021

Available online October 25, 2021

Kata Kunci:

E-Wom, E-Trust, Minat

Keywords:

E-Wom, E-Trust, Interest in Using

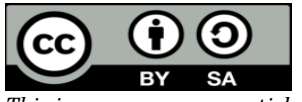

This is an open access article under the $\underline{C C}$ BY-SA license.

Copyright (C) 2021 by Author. Published by Universitas Pendidikan Ganesha.

\begin{abstract}
A B S T R A K
Pandemi Covid-19 menyebabkan keresahan pada masyarakat, sehingga peran aplikasi kesehatan digital sangat penting di masa pandemi. namun posisi aplikasi Alodokter digantikan oleh pesaingnya, sehingga diindikasikan bahwa minat menggunakan Alodokter menurun. Penelitian ini bertujuan untuk menganalisis determinan faktor yang mempengaruhi e-trust dan minat menggunakan aplikasi Alodokter. Populasi pada penelitian ini adalah pengguna aplikasi Alodokter. Penentuan sampel menggunakan insidential sampling, dengan jumlah sampel sebanyak 105 orang responden. Penelitian ini adalah penelitian kuantitatif dengan pendekatan deskriptif. Teknik analisis data mengunakan pendekatan PLS. Hasil penelitian menunjukkan bahwa $E$-WOM berpengaruh positif signifikan terhadap E-Trust pada aplikasi Alodokter. Fitur layanan tidak berpengaruh signifikan terhadap E-Trust pada aplikasi Alodokter. Perceived usefullness berpengaruh positif signifikan terhadap E-Trust pada aplikasi Alodokter. E-WOM tidak berpengaruh signifikan terhadap minat menggunakan pada aplikasi Alodokter. Fitur layanan tidak berpengaruh signifikan terhadap minat menggunakan pada aplikasi Alodokter. Perceived usefullness tidak berpengaruh signifikan terhadap minat menggunakan pada aplikasi Alodokter. E-Trust berpengaruh positif signifikan terhadap minat menggunakan pada aplikasi Alodokter. Implikasi penelitian ini diharapkan dapat menjadi bahan masukan serta pertimbangan bagi manajemen aplikasi Alodokter agar lebih membuka wawasan dalam meningkatkan minat menggunakan aplikasi Alodokter yang dapat dilakukan dengan meningkatkan perceived usefullness dari aplikasi Alodokter.
\end{abstract}

A B S TRACT

Abstract: The Covid-19 pandemic causes unrest in the community, so the role of digital health applications is very important during the pandemic. but the position of the Alodokter application was replaced by its competitors, so it was indicated that the interest in using Alodokter was decreasing. This study aims to analyze the determinants of factors that influence e-trust and interest in using the Alodokter application. The population in this study were users of the Alodokter application. Determination of the sample using incidental sampling, with a total sample of 105 respondents. This research is quantitative research with a descriptive approach. The data analysis technique used the PLS approach. The results showed that E-WOM had a significant positive effect on E-Trust on the Alodokter application. Service features have no significant effect on E-Trust in the Alodokter application. Perceived usefullness has a significant positive effect on E-Trust on the Alodokter application. E-WOM has no significant effect on interest in using the Alodokter application. Service features have no significant effect on interest in using the Alodokter application. Perceived usefullness has no significant effect on interest in using the Alodokter application. E-Trust has a significant positive effect on interest in using the Alodokter application. The implications of this research are expected to be input and consideration for Alodokter application management in order to open up more insight in increasing interest in using the Alodokter application which can be done by increasing the perceived usefullness of the Alodokter application.

\section{PENDAHULUAN}

Kehadiran dan perkembangan internet saat ini telah memberikan berbagai kemudahan bagi pelaku usaha di Indonesia, salah satunya adalah pertumbuhan bisnis online dengan cukup pesat. Hal ini didukung dengan meningkatnya kemudahan komunikasi dan interaksi antara produsen dengan konsumen dalam sebuah bisnis (Agag \& El-Masry, 2016; Fhonna \& Sorayanti Utami, 2018; Kala Kamdjoug et al., 2021; Kusuma, 2011; Song et al., 2021). Pengguna internet di Indonesia juga terbilang cukup tinggi dari sisi jumlah. Indonesia menduduki peringkat kelima sebagai pengguna internet terbanyak per Maret 2019. Data ini menunjukkan bahwa potensi penggunaan internet sebagai sarana dalam melakukan bisnis sangat tinggi, karena jutaan orang akan menggunakan internet sebagai gaya hidup mereka yang erat kaitannya dengan aplikasi online (Liao et al., 2021). Selain di Indonesia, pemanfaatan internet sebagai sarana Kesehatan digital juga telah berkembang dengan pesat di Asia, hal ini ditunjukkan dari data 
Dailysocial.id pada Tahun 2020, menunjukkan bahwa pertumbuhan layanan kesehatan digital di Indonesia mulai berkembang, di samping itu sebaran penggunaan internet yang tidak merata dan kurang optimal memberikan potensi bagi layanan kesehatan digital untuk berbaur dengan vertical industry yang telah ada (Arfi et al., 2021; Bakhtiar et al., 2020; Mekawie \& Hany, 2019). Sehingga, pemanfaatan internet sebagai sarana layanan kesehatan di Indonesia menunjukkan presentase yang cukup tinggi sebesar $5 \%$. Berdasarkan data tersebut, developer aplikasi di Indonesia melihat sebuah peluang untuk mengembangkan layanan e-health, hingga saat ini telah muncul beberapa layanan kesehatan digital diantarannya Alodokter, Halodoc, Dokter.id, KlikDokter, Medika App, GoDok, TanyaDok, Dokter Sehat, Konsula, Medicabo, Homescare, dan lain-lain. Kemunculan e-health tersebut lalu memberikan warna baru pada pemanfaatan internet di Indonesia (Lorente-Martínez et al., 2020; Song et al., 2021).

Kemunculan berbagai macam layanan kesehatan digital membuat persaingan menjadi semakin ketat. Minat menggunakan aplikasi harus ditingkatkan untuk dapat bersaing dan menunjukkan eksistensi. Behavioral intention atau yang disebuat dengan minat berperilaku merupakan keinginan atau niat seseorang dalam melakukan sesuatu (Abubakar \& Ilkan, 2016; Alalwan, 2020; Ismail et al., 2016; Lin et al., 2020; Yuda Bakti et al., 2020). Hal ini berarti bahwa ketika seseorang melakukan perilaku tertentu, sudah didasarkan pada pertimbangan dan persepsi terhadap perilaku tersebut. Sedangkan minat dalam penggunakan sebuah teknologi adalah keinginan seseorang secara terus menerus untuk menggunakan sebuah sistem yang disukainya karena memiliki informasi yang dibutuhkannnya (Adiwijaya, 2018). Minat menggunakan dipengaruhi oleh beberapa faktor, diantaranya E-WOM, Fitur Layanan, Perceived Usefullness, dan E-Trust. Selain itu, E-WOM juga merupakan salah satu faktor yang mempengaruhi minat menggunakan. Word of Mouth (WOM) adalah alat komunikasi pemasaran utama yang telah dipelajari oleh ahli pemasaran dan praktisi. Electronic Word of Mouth (WOM) adalah komunikasi lisan, dari orang ke orang antara peneriman dan komunikator yang dianggap peneriman non-komersial terkait dengan merk, produk atau layanan secara online. Manajemen perusahaan harus lebih cermat dalam mengamati perilaku dan potensi E-WOM dari konsumen terhadap aplikasi tersebut (Tran \& Strutton (2020); Mekawie \& Hany (2019); Bakti et al. (2020); Abubakar \& Ilkan (2016); Park et al., (2021).

Kemunculan virus corona pada Tahun 2019 menyebabkan perubahan pada aspek-aspek kehidupan manusia, kekhawatiran masyarakat akan penyebaran virus corona yang disebut dengan covid19 membuat pemerintah melakukan kebijakan pembatasan kegiatan sosial dan masyarakat di luar rumah (Bakhtiar et al., 2020; Choi et al., 2021; Hsieh et al., 2021). Kemunculan Covid-19 menjadi sebuah pandemi global karena sampai saat ini Covid-19 telah menewaskan puluhan ribu jiwa. Perkembangan kasus Covid19 di Indonesia sendiri terbilang cukup pesat, data terkini (12/6/2020) mencatat 35.295 orang positif, 12.636 orang dinyatakan sembuh dan 2000 orang meninggal dunia (Susilo et al., 2020). Keresahan masyarakat untuk mengunjungi tempat-tempat ramai membuat berbagai aktivitas dilakukan dari rumah saja, dengan bantuan internet sebagai sarana aktivitas digital (Nasution et al., 2020). Penutupan fasilitas umum juga menjadi salah satu kebijakan pemerintah untuk memutus rantai penyebaran covid-19. Fasilitas Kesehatan juga menjadi salah satu yang paling terdampak, karena tenaga kesehatan merupakan ujung tombak dalam menghadapi covid-19, banyak diantara mereka gugur hingga menyebabkan ketakutan masyarakat untuk berobat (Choi et al., 2021; Fitriyani et al., 2020; Hsieh et al., 2021).

Salah satu aplikasi yang berkembang dan dapat dimanfaatkan dengan baik pada kondisi pandemi ini adalah aplikasi konsultasi kesehatan dengan dokter secara daring. Aplikasi daring yang dapat diakses dengan mudah salah satunya adalah aplikasi Alodokter. Alodokter merupakan salah satu aplikasi layanan kesehatan daring yang membantu pengguna melakukan konsultasi kesehatan secara daring melalui smartphone ataupun device lainnya yang mendukung koneksi internet. Pemanfaatan internet dalam bidang Kesehatan di Indonesia menujukkan angka yang cukup tinggi berdasarkan survey oleh Apjii.or.id/survey Tahun 2020 menunjukkan hampir 65 persen pengguna internet di Indonesia pernah mencari informasi ataupun melakukan konsultasi online. Alodokter mampu menempati urutan ke 6 sebagai 10 Startup terbaik Indonesia menurut StartUp ranking per 10 Januari 2019. Alodokter yang didirikan pada tahun 2014, saat ini telah menjadi perantara antara 20.000 dokter dan 20 juta pasien secara online. Katadata.com mencatat bahwa selama masa pandemi Covid-19 kunjungan kepada situs Alodokter tembus 2 juta kunjungan. Sedangkan pencarian informasi terkait Covid-19 pada pesaingnya yaitu Halodoc meningkat 600\%. Hal ini menunjukkan bahwa pemanfaatan aplikasi e-health seperti Alodokter sangat membantu pengguna internet di Indonesia selama masa pandemi. Meskipun sempat menjadi yang terbaik pada startup ranking, Alodokter saat ini mengalami penurunan tren dan digeser oleh aplikasi Halodoc. DSResearch milik Daily Social baru saja melakukan riset pada Oktober 2019 terkait kesehatan (wellness) kaum urban. Bekerja sama dengan FITCO milik FIT Company, DSResearch melakukan riset di Jakarta sebagai kota urban Indonesia untuk menelisik tentang kesehatan penghuninya. Halodoc memimpin dengan penilaian aplikasi yang pernah digunakan. 
Kepercayaan pengguna aplikasi Alodokter sangat penting untuk diperhatikan, karena Alodokter merupakan aplikasi yang melayani konsultasi dan pengobatan medis, maka perusahaan harus memperhatikan aspek kepercayaan pengguna, informasi dan data yang diberikan haruslah tepat dan tidak ada kesalahan sehingga pengguna percaya dengan informasi kesehatan yang diberikan. Urusan Kesehatan merupakan hal yang sangat vital dalam kehidupan manusia, karena kesehatan merupakan dasar dari kehidupan manusia yang dapat menentukan hidup dan kematian, sehingga untuk dapat memunculkan kepercayaan pengguna aplikasi Alodokter diperlukan bukti keandalan dari aplikasi Alodokter. Keandalan ini dapat ditunjukkan oleh Alodokter dengan kompetensi dokter yang terdaftar pada aplikasi, keakuratan diagnose dokter serta ketepatan anjuran obat oleh dokter kepada pasien sehingga akan membentuk rasa percaya pasien dalam menggunakan aplikasi tersebut. Sehingga diindikasikan bahwa e-trust dapat menjadi mediasi pengaruh E-WOM, fitur layanan dan perceived usefulness terhadap minat menggunakan aplikasi Alodokter. Berdasarkan aplikasi kesehatan yang paling sering digunakan, mengindikasikan bahwa minat menggunakan aplikasi Alodokter mengalami penurunan. Minat menggunakan menggunakan adalah salah satu aspek dalam diri konsumen atas sebuah produk atau jasa. Minat menggunakan dipengaruhi oleh beberapa faktor, salah satunya adalah e-WOM. Word of mouth menurut Lovelock et,al (Setyaningsih, 2017) adalah sebuah model pemasaran tidak langsung yang terjadi dari mulut ke mulut, word of mouth merupakan salah satu pemasaran yang efektif karena langsung sampai kepada konsumen melalui konsumen yang sangat mempengaruhi keputusan konsumen.

Beberapa temuan menyatakan satu faktor yang mempengaruhi minat menggunakan fitur layanan (Nawangsari \& Iswah, 2019). perceived usefulness (kebermanfaatan) adalah faktor yang mempengaruhi minat menggunakan layanan (Moslehpour et al., 2018). Perceived usefulness berpengaruh positif terhadap minat menggunakan aplikasi (Izzani et al., 2016). Kepercayaan (trust) berpengaruh positif terhadap keputusan penggunaan layanan internet (Stouthuysen, 2020). Kualitas layanan berpengaruh positif terhadap keputusan nasabah dalam menggunakan e-banking dan word of mouth berpengaruh positif terhadap keputusan nasabah. Penelitian ini menjelaskan bahwa penyebaran informasi melalui mulut ke mulut atau word of mouth memberikan efek yang signifikan terhadap minat pengguna terhadap sebuah aplikasi (Setyaningsih, 2017). Kepercayaan (trust) seorang konsumen dicerminkan melalui harapan yang diberikan konsumen terhadap penyedia jasa bahwa produk yang diterimanya akan sesuai dengan ekspektasinya (Hsieh et al., 2021; Jayantari \& Seminari, 2018; Lu et al., 2021; Sharma \& Klein, 2020; Talwar et al., 2020).

Penelitian ini penting dilakukan karena perilaku konsumen dalam menggunakan aplikasi yang terbilang baru dalam dunia kesehatan digital atau e-health, khususnya dalam menghadapi kondisi pandemi yang menyebabkan pengobatan konvensional susah dilakukan, maka aplikasi Alodokter menjadi salah satu solusi, akan tetapi fenomena penggunaan aplikasi yang masih perlu mendapat kajian karena banyak pesaing sejenis sehingga Alodokter harus menetapkan strategi yang lebih baik. Berdasarkan hasilhasil penelitian di atas, terdapat beberapa variabel yang secara dominan mempengaruhi minat menggunakan sebuah aplikasi, diantaranya adalah word of mouth, fitur layanan dan kebermanfaatan serta semua variabel itu tidak akan berjalan dengan baik apabila tidak dilandasi dengan kepercayaan pelanggan terhadap aplikasi tersebut. Penelitian ini bertujuan untuk menganalisis menganalisis determinan faktor yang mempengaruhi e-trust dan minat menggunakan aplikasi Alodokter. Selain itu, penelitian yang akan dilakukan memiliki beberapa perbedaan dengan penelitian terdahulu di atas, salah satunya adalah terdapat variabel-variabel lain dalam penelitian terdahulu yang tidak diteliti dalam penelitian ini. Selain itu, terdapat penelitian yang menggunakan teknik analisis yang berbeda dengan penelitian yang akan dilakukan.

\section{METODE}

Jenis penelitian ini adalah penelitian kuantitatif dengan pendekatan deskriptif. Data kualitatif yang digunakan dalam penelitian didapatkan melalui berbegai metode, diantaranya adalah wawancara terhadap infiorman atau narasumber, hasil observasi dan juga hasil dokumentasi terhadap sebuat dokumen. Dalam penelitian ini yang tergolong data kualitatif adalah hasil observasi terhadap penggunaan layanan Kesehatan pada masa sebelum pandemi, saat pandemi, dan sesudah pandemi. Sedangkan data kuantitatif dalam penelitian ini adalah skor kuisioner dan data pengguna internet serta pertumbuhan layanan Kesehatan digital. Teknik pengumpulan data menggunakan dokumentasi, wawancara, observasi, dan kuesione. Wawancara adalah sebuah kegiatan menemukan atau mencari informasi yang dilakukan kepada informan atau narasumber dalam sebuah penelitian, bentuk dari wawancara adalah sebuah tanya jawab yang dilakukan peneliti (Sugiyono, 2019). Wawanca dalam sebuah peneltiian sangat bermanfaat sebagai sebuah informasi yang didapatkan langsung dari narasumber sehingga dapat memperkuat data yang disampaikan untuk mendukung penelitian dilakukan. Proses yang terjadi dalam kegiatan observasi 
cukup kompleks karena melibatkan berbagao macam indera, baik pendengaran, pengelihatan ataupun indera perasa dengan tujuan untuk memperoleh data yang akurat dan tepat dalam mendukung proses penelitian tersebut. Observasi yang dilakukan terhadap perilaku pengguna aplikasi Alodokter dalam menggunakan aplikasi, observasi terkait kepuasan penggunaan aplikasi. Kuisioner yang merupakan instrument penelitian dikembangkan berdasarkan indikator yang telah dijabarkan sesuai dengan operasional variabel penelitian. Penyebaran kuesioner dilakukan secara langsung pada pengguna aplikasi Alodokter. Teknik analisis data mengunakan pendekatan PLS.

\section{HASIL DAN PEMBAHASAN}

\section{Hasil}

Berdasarkan hasil analisis menunjukkan bahwa evaluasi model pengukuran (Outler model) dengan Convergent Validity memperlihatkan semua nilai dari faktor loading melebihi angka 0,7 sehingga data yang ada pada penelitian adalah valid. Berdasarkan hasil analisis menunjukkan bahwa nilai AVE yang melebihi angka 0,5 sehingga data yang ada pada penelitian adalah valid.

Tabel 1. Discriminant Validity

\begin{tabular}{cccccc}
\hline & $\begin{array}{c}\text { E-Trust } \\
\text { (Z) }\end{array}$ & $\begin{array}{c}\text { E-WOM } \\
\text { (X1) }\end{array}$ & $\begin{array}{c}\text { Fitur } \\
\text { Layanan } \\
\text { (X2) }\end{array}$ & $\begin{array}{c}\text { Minat } \\
\text { Menggunakan } \\
\text { (Y) }\end{array}$ & $\begin{array}{c}\text { Perceived } \\
\text { Usefullness } \\
\text { (X3) }\end{array}$ \\
\hline E-Trust (Z) & 0,895 & & & & \\
E-WOM (X1) & 0,854 & 0,909 & & & \\
Fitur Layanan (X2) & 0,793 & 0,913 & 0,945 & & \\
Minat Menggunakan (Y) & 0,725 & 0,670 & 0,607 & 0,907 & \\
Perceived Usefullness (X3) & 0,896 & 0,856 & 0,814 & 0,694 & 0,937 \\
\hline
\end{tabular}

Berdasarkan hasil discriminant validity pada Tabel 1 menunjukkan bahwa semua nilai cross loading yang ada pada indikator E-Trust, E-WOM, Fitur Layanan, Minat Menggunakan, Perceived Usefullness mempunyai nilai yang melebihi angka 0,5 sehingga data yang ada pada penelitian adalah valid.

Tabel 2. Koefisien Composite Reliability dan Cronbach's Alpha

\begin{tabular}{ccc}
\hline & Cronbach's Alpha & Composite Reliability \\
\hline E-Trust (Z) & 0,937 & 0,953 \\
E-WOM (X1) & 0,947 & 0,960 \\
Fitur Layanan (X2) & 0,960 & 0,971 \\
Minat Menggunakan (Y) & 0,893 & 0,933 \\
Perceived Usefullness (X3) & 0,931 & 0,956 \\
\hline
\end{tabular}

Berdasarkan hasil analisis pada Tabel 2 menunjukkan bahwa nilai Cronbach's alpha pada indikator E-Trust, E-WOM, Fitur Layanan, Minat Menggunakan, Perceived Usefullness mempunyai nilai yang melebihi angka 0,7 dan semua nilai Composite Reliability pada indikator E-Trust, E-WOM, Fitur Layanan, Minat Menggunakan, Perceived Usefullness mempunyai nilai yang melebihi angka 0,6 sehingga data yang ada pada penelitian adalah reliable.

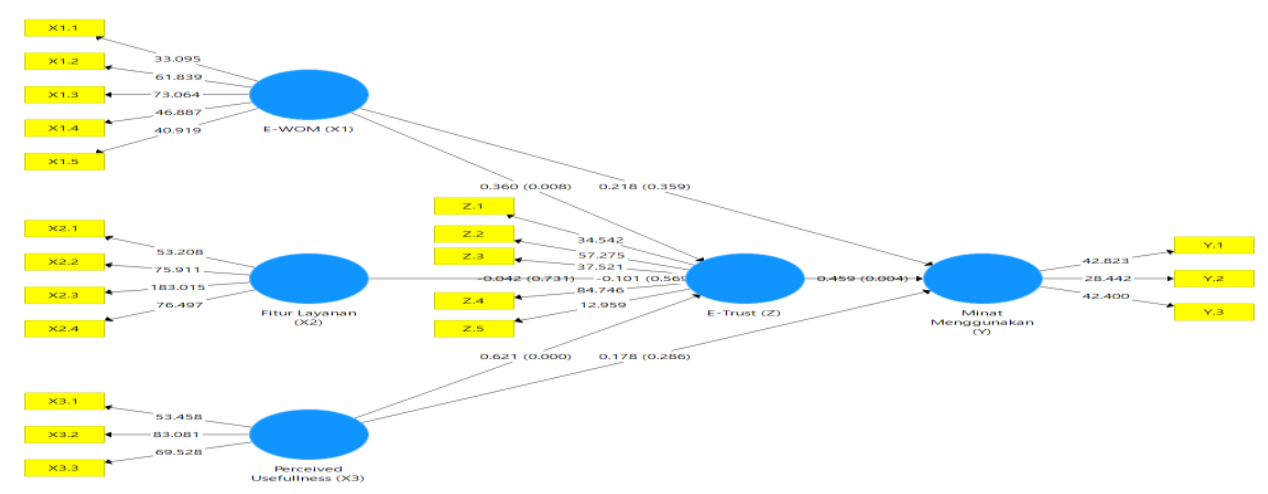

Gambar 1. Inner Model 
Berdasarkan hasil analisis menunjukkan bahwa nilai evaluasi model pengukuran (inner model) diperoleh nilai R square pada variable E-WOM, Fitur Layanan, Perceived Usefullness kepada E-Trust senilai $83,1 \%$, sementara nilai $\mathrm{R}$ square pada variable E-Trust, Fitur Layanan, Perceived Usefullness kepada minat menggunakan senilai $45,1 \%$ dengan nilai $Q$-square senilai 0,922 berada di antara 0 hingga 1 , sehingga model dapat dikatakan mempunyai nilai prediktif yang relevan.

Berdasarkan hasil analisis didapatkan bahwa nilai $p$-value pada variable $E$-WOM kepada $E$-Trust pada aplikasi Alodokter senilai $0,008(0,008<0,05)$, dengan nilai beta senilai 0,360 positif, serta $\mathrm{t}$ statistics $>$ t-value $(2,663>1,96)$. Sehingga, $E$-WOM berpengaruh positif signifikan kepada E-Trust pada aplikasi Alodokter. Berdasarkan hasil analisis didapatkan bahwa nilai $p$-value pada variable fitur layanan kepada E-Trust pada aplikasi Alodokter senilai 0,731 $(0,731<0,05)$, dengan nilai beta senilai 0,042 negatif, serta t-statistics < t-value $(0,344<1,96)$. Sehingga, fitur layanan tidak berpengaruh signifikan kepada E-Trust pada aplikasi Alodokter. Berdasarkan hasil analisis didapatkan bahwa nilai $p$-value pada variable perceived usefullness kepada $E$-Trust pada aplikasi Alodokter senilai $0,000(0,000<0,05)$, dengan nilai beta senilai 0,621 positif, serta t-statistics $>\mathrm{t}$-value $(8,661>1,96)$. Sehingga, perceived usefullness berpengaruh positif signifikan kepada $E$-Trust pada aplikasi Alodokter. Nilai $p$-value pada variable $E$-WOM kepada minat menggunakan pada aplikasi Alodokter senilai 0,359 $(0,359>0,05)$, dengan nilai beta senilai 0,218 positif, serta t-statistics $<$ t-value $(0,919<1,96)$. Sehingga, $E$-WOM tidak berpengaruh signifikan kepada minat menggunakan pada aplikasi Alodokter. Nilai $p$-value pada variable fitur layanan kepada minat menggunakan pada aplikasi Alodokter senilai 0,569 $(0,569>0,05)$, dengan nilai beta senilai 0,101 negatif, serta t-statistics < t-value $(0,570<1,96)$. Sehingga, fitur layanan tidak berpengaruh signifikan kepada minat menggunakan pada aplikasi Alodokter. Nilai $p$-value pada variable perceived usefullness kepada minat menggunakan pada aplikasi Alodokter senilai 0,286 $(0,286>0,05)$, dengan nilai beta senilai 0,178 positif, serta $t$-statistics $<\mathrm{t}$-value $(1,068<1,96)$. Sehingga, perceived usefullness tidak berpengaruh signifikan kepada minat menggunakan pada aplikasi Alodokter. Hasil analisis didapatkan bahwa nilai $p$ value pada variable E-Trust kepada minat menggunakan pada aplikasi Alodokter senilai 0,004 $(0,004<$ $0,05)$, dengan nilai beta senilai 0,459 positif, serta t-statistics $>$ t-value $(2,904>1,96)$. Sehingga, $E$-Trust berpengaruh positif signifikan kepada minat menggunakan pada aplikasi Alodokter.

\section{Pembahasan}

Berdasarkan hasil penelitian bahwa E-WOM yang merupakan pernyataan positif atau negative dari konsumen terhadap produk mempengaruhi minat menggunakan sebuah produk. Bagi aplikasi, minat menggunakan konsumen dapat meningkat ketika e-WOM pada aplikasi tersebut positif. Artinya banyak konsumen yang menyatakan aplikasi tersebut baik dan layak digunakan sehingga minat menggunakan aplikasi tersebut dapat meningkat pula. Electronic Word of Mouth (e-WOM) merupakan sebuah bentuk pemasaran dari mulut ke mulut secara digital terhadap perasaan negatif atau positif dari sebuah produk. Hal ini menyebabkan adanya pertukaran informasi yang terjadi antara calon pengguna dengan pengguna yang memberikan ulasan online. E-WOM memiliki pengaruh terhadap kepercayaan pengguna, jika e-WOM yang muncul terhadap sebuah aplikasi positif maka kepercayaan calon pengguna terhadap aplikasi terhsebut akan meningkat begitu sebaliknya. Melalui kepercayaan, konsumen dapat menumbuhkan keinginan untuk mulai menggunakan sebuah produk atau jasa tertentu (Hsieh et al., 2021; Jayantari \& Seminari, 2018; Lu et al., 2021; Sharma \& Klein, 2020; Talwar et al., 2020). Kepercayaan juga berarti penyedia layanan jasa atau produk memiliki reputasi yang baik di mata konsumen, khusus untuk penyedia jasa layanan digital, kepercayaan sangatlah penting, karena antara konsumen dengan penyedia layanan tidak bertatap muka langsung, oleh karena itu kepercayaan menjadi faktor utama konsumen menggunakan jasa layanan tersebut. Adanya E-WOM atau electronic word of mouth dapat meningkatkan kepercayaan pengguna, atau ada pengaruh yang positif dari E-WOM terhadap e-trust (Fhonna \& Sorayanti Utami, 2018).

Berdasarkan hasil analisis didapatkan bahwa Fitur layanan dalam sebuah aplikasi merupakan salah satu modal dalam penjualan. Fitur diberikan untuk memudahkan pekerjaan dan memenuhi harapan pengguna. Ketika fitur layanan dirasa sudah dapat memenuhi kebutuhan pengguna maka minat menggunakan aplikasi akan meningkat. Begitu sebaliknya jika fitur dalam sebuah aplikasi tidak lengkap dan tidak dapat memenuhi ekspektasi pengguna maka minat menggunakan pengguna aplikasi akan menurun. Fitur layanan yang dimiliki oleh sebuah teknologi sangat bermanfaat bagi pengguna, oleh sebab itu adanya fitur layanan pada sebuah teknologui dapat meningkatkan kepercayaan terhadap teknologi tersebut. Sebuah fitur muncul akibat adanya kebutuhan yang ingin dipenuhi oleh pengembang sebuah teknologi untuk penggunanya. Oleh karena itu, fitur yang dikembangkan seharusnya memberikan kemudahan dan manfaat yang lebih dari produk-produk pesaing lainnya (Nawangsari \& Iswah, 2019). Fitur harus mempertimbangkan efisiensi dari pekerjaan penggunanya sehingga pengguna akan senang dengan fitur yang dihadirkan dan semakin bagus fitur layanan sebuah aplikasi, semakin tinggi kepercayan 
pengguna terhadap aplikasi tersebut. keberadaan fitur merupakan salah satu yang memperikan karakter pada sebuah produk atau layanan. Fitur merupakan alasan yang kuat bagi konsumen untuk memilih sebuah produk. Fitur layanan aplikasi Kesehatan digital merupakan sebuah nilai tambah yang harus dimiliki sebuah aplikasi, karena esensi kemunculan aplikasi tersebut adalah untuk memudahkan kehidupan manusia dalam melakukan aktivitasnya (Gao \& Huang, 2019; Ismail et al., 2016).

Berdasarkan hasil analisis didapatkan bahwa kebermanfaatan sebuah aplikasi dalam menunjang kebutuhan manusia dapat meningkatkan minat menggunakan aplikasi tersebut. Hal ini karena seorang pengguna akan selalu mencari manfaat dari sebuah aplikasi sehingga ada hubungan era tantara kebermanfaatan terhadap minat menggunakan aplikasi. Selain itu, persepsi kebermanfaatan merupakan sebuah anggapan dari pengguna yang menyatakan bahwa adanya teknologi yang digunakan dapat meningkatkan produktivitas kerja dari pengguna (Izzani et al., 2016). Perceived Usefulness adalah salah satu aspek yang dipertimbangan oleh pengguna sehingga menjadi tolok ukur untuk mengetahui kepercayaan pengguna terhadap teknologi tersebut (Moslehpour et al., 2018). Perceived usefulness terhadap kepercayaan atau $e$-trust merupakan hal yang saling berkaitan, hal ini karena untuk membangun sebuah kepercayaan pada diri pengguna, sebuh teknologi harus memiliki kebermanfaatan di mata penggunanya (Nawangsari \& Iswah, 2019). Pengguna yang merasakan manfaat teknologi yang digunakannya akan cenderung muncul rasa percaya bahwa teknologi tersebut dapat memenuhi ekspektasinya. Adanya keselarasan antara persepsi kebermanfaatan sebuah teknologi dengan kepercayaan penggunanya (Nawangsari \& Iswah, 2019).

Berdasarkan kepercayaan juga merupakan salah satu faktor yang mempengaruhi minat menggunakan sebuah aplikasi. Kepercayaan adalah modal penting yang dimiliki perusahaan saat memiliki pengguna yang loyal terhadap produk yang dimilikinya. Aplikasi Alodokter tentunya memberikan manfaat dari sisi pelayanan Kesehatan digital yang membantu pasien untuk menerima layanan Kesehatan dengan lebih cepat dan efisien. Temuan ini diperkuat dengan temuan sebelumnya yang menyatakan bahwa perceived usefulness berpengaruh positif terhadap minat menggunakan aplikasi (Izzani et al., 2016). Persepsi kebermanfaatan dari sebuah teknologi dapat memberikan dampak positif terhadap minat menggunakan produk teknologi tersebut (Nawangsari \& Iswah, 2019). Namun penelitian ini tidak sejalan dengan penelitian sebelumnya yang menyatakan adanya $e$-WOM dapat memberikan pengaruh yang positif terhadap minat menggunakan sebuah teknologi (Hsu et al., 2017; Tran \& Strutton, 2020). Dari pembahasan tersebut $E$-WOM berpengaruh positif signifikan terhadap E-Trust pada aplikasi Alodokter. EWOM menjadi salah satu faktor yang mempengaruhi minat menggunakan. Word of Mouth (WOM) adalah alat komunikasi pemasaran utama yang telah dipelajari oleh ahli pemasaran dan praktisi. Electronic Word of Mouth (WOM) adalah komunikasi lisan, dari orang ke orang antara peneriman dan komunikator yang dianggap peneriman non-komersial terkait dengan merk, produk atau layanan secara online.

\section{SIMPULAN}

E-WOM berpengaruh positif signifikan terhadap E-Trust pada aplikasi Alodokter. Fitur layanan tidak berpengaruh signifikan terhadap E-Trust pada aplikasi Alodokter. Perceived usefullness berpengaruh positif signifikan terhadap E-Trust pada aplikasi Alodokter. E-WOM tidak berpengaruh signifikan terhadap minat menggunakan pada aplikasi Alodokter. Fitur layanan tidak berpengaruh signifikan terhadap minat menggunakan pada aplikasi Alodokter. Perceived usefullness tidak berpengaruh signifikan terhadap minat menggunakan pada aplikasi Alodokter. E-Trust berpengaruh positif signifikan terhadap minat menggunakan pada aplikasi Alodokter. Hasil ini menjadi pertimbangan bagi manajemen aplikasi Alodokter agar lebih membuka wawasan dalam meningkatkan minat menggunakan aplikasi Alodokter yang dapat dilakukan dengan meningkatkan perceived usefullness dari aplikasi Alodokter.

\section{DAFTAR PUSTAKA}

Abubakar, A. M., \& Ilkan, M. (2016). Impact of online WOM on destination trust and intention to travel: A medical tourism perspective. Journal of Destination Marketing and Management, 5(3), 192-201. https://doi.org/10.1016/j.jdmm.2015.12.005.

Adiwijaya, I. G. B. P. (2018). Kemudahan Penggunaan, Tingkat Keberhasilan Transaksi, Kemampuan Sistem Teknologi, Kepercayaan dan Minat Bertransaski Menggunakan Mobile Banking. Jurnal Manajemen Dan Bisnis, 15(3), 135-153. https://doi.org/10.38043/jmb.v15i3.611.

Agag, G., \& El-Masry, A. A. (2016). Understanding consumer intention to participate in online travel community and effects on consumer intention to purchase travel online and WOM: An integration of innovation diffusion theory and TAM with trust. Computers in Human Behavior, 60(2), 97-111. https://doi.org/10.1016/j.chb.2016.02.038. 
Alalwan, A. A. (2020). Mobile food ordering apps: An empirical study of the factors affecting customer esatisfaction and continued intention to reuse. International Journal of Information Management, 50(3), 28-44. https://doi.org/10.1016/j.ijinfomgt.2019.04.008.

Arfi, W. Ben, Nasr, I. Ben, Kondrateva, G., \& Hikkerova, L. (2021). The role of trust in intention to use the IoT in eHealth: Application of the modified UTAUT in a consumer context. Technological Forecasting and Social Change, 167(7). https://doi.org/10.1016/j.techfore.2021.120688.

Bakhtiar, M., Elbuluk, N., \& Lipoff, J. B. (2020). The digital divide: How COVID-19's telemedicine expansion could exacerbate disparities. In Journal of the American Academy of Dermatology (Vol. 83, Issue 5, pp. e345-e346). https://doi.org/10.1016/j.jaad.2020.07.043.

Choi, K., Gitelman, Y., Leri, D., Deleener, M. E., Hahn, L., O’Malley, C., Lang, E., Patel, N., Jones, T., Emperado, K., Erickson, C., Rosin, R., Asch, D., Hanson, C. W., \& Adusumalli, S. (2021). Insourcing and scaling a telemedicine solution in under 2 weeks: Lessons for the digital transformation of health care. Healthcare, 9(3). https://doi.org/10.1016/j.hjdsi.2021.100568.

Fhonna, R. A., \& Sorayanti Utami. (2018). Pengaruh electronic word of mouth terhadap keterlibatan keputusan pembelian dan kepercayaan sebagai pemediasi pada konsumen shopee di Universitas Syiah Kuala. Jurnal Ilmiah Mahasiswa Ekonomi Manajemen, 3(3), 20-32. https://doi.org/10.24815/jimen.v3i3.8081.

Fitriyani, I., Sudiyarti, N., \& Fietroh, M. N. (2020). Strategi Manajemen Bisnis Pasca Pandemi COVID-19. Indonesian Journal of Social Sciences and Humanities, 1(2), 87-95. https: //doi.org/10.15797/concom.2019..23.009.

Gao, B., \& Huang, L. (2019). Understanding interactive user behavior in smart media content service: An integration of TAM and smart service belief factors. Heliyon, 5(12). https://doi.org/10.1016/j.heliyon.2019.e02983.

Hsieh, Y. (Jerrie), Chen, Y. L., \& Wang, Y. C. (2021). Government and social trust vs. hotel response efficacy: A protection motivation perspective on hotel stay intention during the COVID-19 pandemic. International Journal of Hospitality Management, 97(7). https://doi.org/10.1016/j.ijhm.2021.102991.

Hsu, C. L., Chen, Y. C., Yang, T. N., \& Lin, W. K. (2017). Do website features matter in an online gamification context? Focusing on the mediating roles of user experience and attitude. Telematics and Informatics, 34(4), 196-205. https://doi.org/10.1016/j.tele.2017.01.009.

Ismail, M. N. I., Hanafiah, M. H., Aminuddin, N., \& Mustafa, N. (2016). Community-based Homestay Service Quality, Visitor Satisfaction, and Behavioral Intention. Procedia - Social and Behavioral Sciences, 222(2), 398-405. https://doi.org/10.1016/j.sbspro.2016.05.192.

Izzani, M., Marzuki, I., Rosly, A. N., Roslan, N. S., Abdullah, D., Bahri, S., Kamal, M., \& Azmi, A. (2016). The role of perceived interactivity, perceived ease of use, perceived usefulness, and perceived enjoyment toward intention to use online mapping service applications. International Academic Research Journal of Business and Technology, 2(2), 135-139. https: //www.researchgate.net/publication/311676123.

Jayantari, I. A. A. U., \& Seminari, N. K. (2018). Peran Kepercayaan Memediasi Persepsi Risiko terhadap Niat Menggunakan Mandiri Mobile Banking di Kota Denpasar. E-Jurnal Manajemen Universitas Udayana, 7(5), 2621. https://doi.org/10.24843/ejmunud.2018.v07.i05.p13.

Kala Kamdjoug, J. R., Wamba-Taguimdje, S. L., Wamba, S. F., \& Kake, I. B. E. (2021). Determining factors and impacts of the intention to adopt mobile banking app in Cameroon: Case of SARA by afriland First Bank. Journal of Retailing and Consumer Services, 61(1). https: //doi.org/10.1016/j.jretconser.2021.102509.

Kusuma, R. (2011). Evaluasi Penerapan Sistem Informasi Manajemen Keimigrasian (SIMKIM) Kantor Imigrasi Kelas I Yogyakartaf. Jurnal Fisip Umrah, 1.(1), 287-295. https: //doi.org/10.1016/j.sbspro.2015.04.

Liao, S. H., Hu, D. C., Chung, Y. C., \& Huang, A. P. (2021). Risk and opportunity for online purchase intention - A moderated mediation model investigation. Telematics and Informatics, 62(2). https: //doi.org/10.1016/j.tele.2021.101621.

Lin, W. R., Lin, C. Y., \& Ding, Y. H. (2020). Factors affecting the behavioral intention to adopt mobile payment: An empirical study in Taiwan. Mathematics, 8(10), 1-19. https://doi.org/10.3390/math8101851.

Lorente-Martínez, J., Navío-Marco, J., \& Rodrigo-Moya, B. (2020). Analysis of the adoption of customer facing InStore technologies in retail SMEs. Journal of Retailing and Consumer Services, 57(7). https://doi.org/10.1016/j.jretconser.2020.102225.

Lu, B., Wang, Z., \& Zhang, S. (2021). Platform-based mechanisms, institutional trust, and continuous use intention: The moderating role of perceived effectiveness of sharing economy institutional 
mechanisms. Information and Management, 58(7). https://doi.org/10.1016/j.im.2021.103504.

Mekawie, N., \& Hany, A. (2019). Understanding the Factors Driving Consumers' Purchase Intention of over the Counter Medications Using Social Media advertising in Egypt. Procedia Computer Science, 164(4), 698-705. https://doi.org/10.1016/j.procs.2019.12.238.

Moslehpour, M., Pham, V. K., Wong, W. K., \& Bilgiçli, I. (2018). e-purchase intention of Taiwanese consumers: Sustainable mediation of perceived usefulness and perceived ease of use. Sustainability (Switzerland), 10(1). https://doi.org/10.3390/su10010234.

Nasution, D. A. D., Erlina, E., \& Muda, I. (2020). Dampak Pandemi CoVID-19 terhadap Perekonomian Indonesia. Jurnal Benefita, 5(2), 212. https://doi.org/10.22216/jbe.v5i2.5313.

Nawangsari, S., \& Iswah, S. N. (2019). Pengaruh Teknologi Informasi, Persepsi Manfaat, Persepsi Kemudahan, dan Fitur Layanan terhadap Kepuasan Nasabah serta Implikasinya pada Minat Ulang Penggunaan Aplikasi Jenius Bank BTPN. Seminar Nasional APTIKOM (SEMNASTIK), 1(1), 144-151. https://publikasi.dinus.ac.id/index.php/semnastik/article/view/2777.

Park, C. W., Sutherland, I., \& Lee, S. K. (2021). Effects of online reviews, trust, and picture-superiority on intention to purchase restaurant services. Journal of Hospitality and Tourism Management, 47(7), 228-236. https://doi.org/10.1016/j.jhtm.2021.03.007.

Setyaningsih, E. D. (2017). Pengaruh Kualitas Layanan Dan Word Of Mouth Melalui Minat Terhadap Keputusan Nasabah Dalam Menggunakan E-Banking Pada Bank Bni. Jurnal Ilmiah Ekonomi Bisnis, 22(1). https://ejournal.gunadarma.ac.id/index.php/ekbis/article/view/1506.

Sharma, V. M., \& Klein, A. (2020). Consumer perceived value, involvement, trust, susceptibility to interpersonal influence, and intention to participate in online group buying. Journal of Retailing and Consumer Services, 52(2). https://doi.org/10.1016/j.jretconser.2019.101946.

Song, H. J., Ruan, W. J., \& Jeon, Y. J. J. (2021). An integrated approach to the purchase decision making process of food-delivery apps: Focusing on the TAM and AIDA models. International Journal of Hospitality Management, 95(5). https://doi.org/10.1016/j.ijhm.2021.102943.

Stouthuysen, K. (2020). The building of online trust in e-business relationships. Electronic Commerce Research and Applications, 4(10). https://doi.org/10.1016/j.elerap.2020.100929.

Sugiyono, P. D. (2019). MetodePenelitian Kuantitatif, Kualitatif dan R\&D. Bandung: PT Alfabet. In Sugiyono. (2019). MetodePenelitian Kuantitatif, Kualitatif dan R\&D. Bandung: PT Alfabet. https://doi.org/10.1017/CB09781107415324.004

Susilo, A., Rumende, C. M., Pitoyo, C. W., Santoso, W. D., Yulianti, M., Herikurniawan, H., Sinto, R., Singh, G., Nainggolan, L., Nelwan, E. J., Chen, L. K., Widhani, A., Wijaya, E., Wicaksana, B., Maksum, M., Annisa, F., Jasirwan, C. O. M., \& Yunihastuti, E. (2020). Coronavirus Disease 2019: Tinjauan Literatur Terkini. Jurnal Penyakit Dalam Indonesia, 7(1), 45. https://doi.org/10.7454/jpdi.v7i1.415.

Talwar, S., Dhir, A., Khalil, A., Mohan, G., \& Islam, A. K. M. N. (2020). Point of adoption and beyond. Initial trust and mobile-payment continuation intention. Journal of Retailing and Consumer Services, 55(5). https://doi.org/10.1016/j.jretconser.2020.102086.

Tran, G. A., \& Strutton, D. (2020). Comparing email and SNS users: Investigating e-servicescape, customer reviews, trust, loyalty and E-WOM. Journal of Retailing and Consumer Services, 53(3). https://doi.org/10.1016/j.jretconser.2019.03.009.

Yuda Bakti, I. G. M., Rakhmawati, T., Sumaedi, S., Widianti, T., Yarmen, M., \& Astrini, N. J. (2020). Public transport users' WOM: An integration model of the theory of planned behavior, customer satisfaction theory, and personal norm theory. Transportation Research Procedia, 48(05), 33653379. https://doi.org/10.1016/j.trpro.2020.08.117. 